\title{
TOPLUMDA GÖRÜLEN ŞİDDET DAVRANIŞINA EVRIMMSEL YAKLAŞIM
}

\author{
REVIEW OF VIOLENCE BEHAVIOR IN HUMANS FROM THE \\ EVOLUTIONARY PERSPECTIVE
}

\section{Melike CEYLAN ${ }^{*}$}

\begin{abstract}
ÖZ: Evrimsel psikoloji; hayatta kalma, ortama uyum sağlama ve tüm psikolojik olguları anlamaya yönelik temel bir çatı oluşturan bir bilim dalı olarak karşımıza çıkmaktadır. Şiddet davranışı evrimsel psikolojik bakış açısıyla açıklandığında, insanların hayatta kalma ve ortama uyum sağlamalarında rol oynadığı düşünülmektedir. Bunun yanı sıra, şiddet davranışı zaman içerisinde kültürün etkisiyle farklılaşmış ve hayatta kalma mekanizması olmanın dışına çıkmaya başlamıştır. Erkeklerde ve kadınlarda şiddet davranışı, toplu şiddet, öz kıyım, cinayet, tecavüz gibi şiddet davranışlarının evrimsel psikoloji çerçevesinde tartışılması ve açıklanması şiddet davranışı kabul edilebilir kılmamakla birlikte, bu davranışlara ait dinamiklerin daha iyi anlaşılması açısından önem taşımaktadır. Şiddet olgusunun evrimsel bakış açısından ele alınması, şiddetin ilkel nedenlerine dair açıklamalar sunmaktadır. Günümüzde şiddeti sadece bu bakış açısıyla açıklamak mümkün olmamakla birlikte sosyolojik, biyolojik ve psikolojik açıklamalar da göz ardı edilmemelidir.
\end{abstract}

Anahtar Kelimeler: Evrim, adaptasyon, şiddet, saldırganlık, eş şiddeti.

ABSTRACT: Evolutionary psychology is the field of a psychology that explains human behaviors of surviving and adaptation skills. Evolutionary psychology is the field of psychology that helps to explain humans' skills of survival and adaptation. When we explain aggression by evolutionary psychology perspective, aggressive behavior seems to be the crucial part of survival and adaptation. In addition to that, aggressive behavior is diverted within time with culture and it passed beyond being a survival mechanism. Topics like violence in men and women, collective violence, suicide, homicide and rape are important to be discussed and explained by evolutionary psychology perspective to understand its dynamics. An evolutionary view of the phenomenon of violence may emerge explanations for the primitive ages of violence. Today, although it is not possible to explain violence solely with this point of view, sociological, biological and psychological explanations should not be ignored at all.

Keywords: Evolution, adaptation, violence, aggression, intimate partner violence.

\section{Giriş}

Dünya Sağlık Örgütü, Dünya Şiddet ve Sağlık Raporu' nda (Dünya Sağlık Örgütü, 2002) şiddet kavramını, fiziksel gücün kişinin kendisine, bir başkasına, bir gruba ya da bir topluluğa karşı uygulanması sonucunda fiziksel zarara, psikolojik zarara, ölüme, gelişim sorunlarına ya da

\footnotetext{
* Dr. Öğretim Üyesi - İstanbul Ayvansaray Üniversitesi İktisadi, İdari ve Sosyal Bilimler Fakültesi Psikoloji Bölümü / İstanbul - melikeceylanpsy@gmail.com (Orcid ID:0000-00018603-8912)
}

This article was checked by Turnitin. 
yoksunluğa istemli olarak neden olması şeklinde tanımlamıştır. Çocuklar, kadınlar ve yaşlılar şiddete en çok maruz kalan gruplardır. Bunun yanı sıra bireysel şiddet toplu şiddeti tetikleyen bir faktör olarak da karşımıza çıkmaktadır. (Polat, 2017).

Evrimsel psikoloji, her şeyden önce bir içerik alanı değil, insan zihnini incelemeye yönelik bir yaklaşımdır. Görsel algı, akıl yürütme, hafıza veya sosyal etkileşim gibi, psikolojiyle ilgili herhangi bir konuya ilişkin uygulanabilecek bir düşünme yolu olarak açlklanabilir (Cosmides ve Tooby, 2000). Adaptasyonist yaklaşımla davranışların bilişsel temellerini araştıran bir bilim dalı olan evrimsel psikolojiye göre insanlar, doğal seçilimin ürünleridir. Bu nedenden dolayı insan türünü doğal dünyadan bağımsızmış gibi kabul eden bir bakış açısı benimseyememektedir (Geher, 2006). Evrimsel psikoloji, canlıların çevrelerine adapte olma sürecinde yaşadıkları baskıları, bu baskılar sonucunda doğal seçilim ile evrimleşen stratejileri ve bu stratejilerin günümüzde nasıl ortaya konulduğuyla ilgilenmektedir (Crawford ve Anderson,1989; Diamond, 1997). Evrimsel psikolojiye göre insanlık, var oluşundan beri pek çok problem ile yüzleşmekte ve bu problemlere karşı başa çıkma mekanizmaları geliştirmiş ve geliştirdikleri bu başa çıkma mekanizmalarını karşılaştıkları problemleri çözmekte kullanmaktadır. Bunun yanı sıra, bazı bireyler ise diğerlerine göre karşılaştı̆̆ problemleri çözme konusunda daha başarılı olmaktadır. Böylelikle başarılı olan bireyler hayatta kalacak ve genlerini bir sonraki nesillere aktaracak olan üreme davranışını sergileyebilecektir. Yapılan pek çok araştırmada genler ve zeka (Bouchard, 2014), alzheimer (Bufil ve ark., 2013) ve hatta aşka (Buss, 2018) bile evrimsel açıklamalar sunulmaktadır.

Canlılar tarafından zaman içerisinde geliştirilen problem çözme yetenekleri, doğal seçilimin sonucunda fonksiyonel adaptasyon haline gelmekte ve günümüze kadar ulaştığı görülmektedir. Bu adaptasyonların yan ürünü olarak şiddet davranışı meydana gelebilmektedir. Doğal seçilimle birlikte adaptasyonların geliştirilmesi, bireylerin ve grupların bazı davranış örüntülerini göstermelerinde yol açabilmektedir. Erkeklerde ve kadınlarda görülen şiddet davranışı, gruplar arası çatışma, öz kıyım ve tecavüz gibi şiddet davranışları, evrimsel psikoloji bakış açısıyla değerlendirilecektir.

\section{Erkeklerde ve Kadınlarda Şiddet Davranışı}

Türkiye'de şiddet, 6284 sayılı ailenin korunması ve kadına karşı şiddetin önlenmesine iliş̧in kanunda "Kişinin fiziksel, cinsel, psikolojik veya ekonomik açıdan zarar görmesiyle veya acı çekmesiyle sonuçlanan veya sonuçlanması muhtemel hareketleri, buna yönelik tehdit ve baskıyı ya da özgürlüğün keyfi engellenmesini de içeren, toplumsal, kamusal veya özel alanda meydana gelen fiziksel, cinsel, psikolojik, sözlü veya ekonomik her türlü tutum ve davranışı" olarak tanımlamaktadır. Şiddet davranışı genellikle erkek üzerinden tartışılmasının yanı sıra, mağdurların yaşlılar, kadınlar ve çocukların olduğu bir problem olarak karşımıza çıkmaktır. Evde gerçekleşen şiddetin ise genellikle erkek tarafından kaynaklandığ 
görülmektedir (Marlborough, 2003). Türkiye'de yapılan Kadına Yönelik Aile İçi Şiddet Araştırması' nda (Kadının Statüsü Genel Müdürlüğü, 2019) ülke genelinde yaşamının herhangi bir döneminde eşi veya eski eşi tarafından fiziksel şiddete maruz bırakılan kadınların oranı \%36'dır. Yaşamının herhangi bir döneminde duygusal şiddet yaşayan kadınların oranı ise \%44'tür. 2014 araştırmasında yaşamının herhangi bir döneminde cinsel şiddete maruz kalan kadınların oranı \%12 olarak karşımıza çıkmaktadır. Son zamanlarda yapılan çalışmaların gösterdiği üzere eşleri tarafından öldürülen kadınların sayıları da git gide artmaktadır (Wilson, 2005).

Saldırganlığa evrimsel psikoloji açısından bakıldığında bazı adaptif problemler, şiddeti doğuran etkenler olarak karşımıza çıkabilmektedir. Eş şiddetine yol açan adaptif problemleri şöyle sıralayabiliriz; kaçak avcıların varlığı (mate poachers), cinsel sadakatsizlik, dişinin başka bir erkeğin yavrusunu taşıma şüphesi, kaynakların sınırlılığı, eş değer tutarsızlığı (mate value disperancy), üvey evlatlar, eşliğin sonlanması ve eski eșin yeniden eş bulmasını engelleme (Buss ve Duntley, 2011). Bu problemler doğrudan seçilmiş adaptasyonlar olabilmekle birlikte sorunları çözebilme amacıyla oluşan adaptasyonların yan ürünü (by-product) olarak da karşımıza çlkabilmektedir (Ward ve Siegert, 2002; Durrant, 2011).

İnsanlar, zaman içerisinde diğer insanları etkilemek ve üreme başarısını (reproductive sucess) arttıran kaynakları edinmek amacıyla pek çok taktik edinmiştir (Buss, Gomes, Giggins ve Lauterbach, 1987). Evrimsel bakış açısında tüm türlerin evrimsel geçmiş ve nihai amaç olan üreme başarısı ile şekillendiği bilinmektedir. Üreme başarısını belirleyen bir faktör olan uzun süreli eşleşme stratejisi, erkeğe üreme açısından pek çok fayda sağlamaktadır. Bunlar faydalar; (1) arzu edilen bir eşi cezbetme yeteneklerini artırmak; (2) uzun süreli yakınlık ve cinsel erişim yoluyla babalık kesinliğini artırmak; (3) çocuklarının hayatta kalmasını sağlamayı arttırmak; (4) baba yatırımı yoluyla çocuklarının üreme başarısını arttırmak; ve (5) karısının geniş akrabaları aracılığıyla statü ve koalisyonel müttefikleri artırmak olarak sayılabilmektedir. (Buss, 2011; Buss, 2018). Uzun süreli ilişki kurmanın üreme başarısı üzerindeki etkisini göz önünde bulunduracak olursak, uzun süreli ilişkiyi elde tutarken de şiddete başvurulması kaçınılamaz bir hale gelmektedir. Erkek tarafından gösterilen şiddet davranışı, evrimsel psikoloji çerçevesinden ele alındığında; üreme başarısını arttırmak, genlerin bir sonraki kuşağa aktarma şansını yükseltmek olarak açıklanmaktadır (Buss ve Duntley, 2011).

Bazı durumlarda erkeklerde ortaya çıkabilen, doğan veya doğacak olan yavrunun kendisine ait olup olmadığı şüphesini azaltmak hatta bu şüpheyi ortadan kaldırmak adına erkek, şiddete başvurulabilmektedir. Buna göre, erkekler tarafindan gerçekleştirilen eşe karşı şiddet ve tehditin, eşlerinin özerkliğini kısıtlamak ve böylece sadakatsizlik riskini düşürmek için strateji olarak kullanılmasından kaynaklı olduğu söylenebilir (Daly ve Wilson, 1988). Bu davranışla birlikte kadının başka bir erkekten yavru 
meydana getirme olasılığını düşürmek ve başka bir erkeğin yavrusuna bakma ihtimalinin ortadan kaldırılması amaçlanır. Erkeklerin sahip olduğu bu şüphenin altında yatan sebebi şöyle açıklamak mümkündür; biyolojik farklılıklara bağlı olarak dişi ve erkek türlerin üreme başarısını güvene alma stratejileri farklı biçimlerde meydana gelmektedir. Bu stratejilerden birisi de kıskançlıktır (Wilson ve Daly, 1999). Ancak cinsiyet rollerinden doğan bir sonuca bağlı olarak dişi ve erkeklerdeki kıskançlığın farklı yaşandığı bilinmektedir (Buss ve Duntley, 2011). Ancak kıskançlıktan bahsetmeden önce ebeveyn yatırım hipotezini anlamak önem taşımaktadır.

Ebeveyn yatırımı hipotezi, hem insanlarda hem de hayvanlar aleminde yaygın olmakla birlikte türlerin çoğunda her ebeveynin yavrularına yatırım yaptığı süre miktarında bir dengesizlik olduğu gerçeğinden kaynaklanmaktadır. Ebeveyn yatırımı, yavruların hayatta kalmasının bir belirleyicisi olarak işlev görür ve bu yatırıma erişmek diğer ebeveyne kıyasla fazla ebeveyn yatırımı sağlamayan cinsiyet için önemlidir. Bu hipotez, yavrularını büyütmeye en çok yatırım yapan cinsiyetin sınırlayıcı cinsiyet olduğunu belirtmektedir. Buna göre bir eş seçerken daha çok yatırım yapan cinsiyet daha seçicidir. Diğer cinsiyet böylece zamanının çoğunu eşler için rekabet etmeye ve kur yapmaya harcamaktadır (Trivers, 1972). Sinırlayıcı cinsiyete göre cinsel seçilim, cinsiyetler arasındaki ebeveyn yatırımı arasındaki eşitsizlik arttıkça daha güçlü bir hale gelmektedir. Ebeveyn yatırımı insanlarda nispeten eşitken, dişiler seçici cinsiyettir çünkü erkekler birkaç dişiyi hamile bırakabilirken, bir dişi yalnızca bir erkekten hamile kalabilir ve hamilelik uzun süren bir dönemdir. Bununla birlikte, erkeklerin yaptığı yatırım, erkeklerin de seçici olduğu anlamına gelmektedir. Evrimsel psikolojiye göre, ebeveyn yatırımı dişilerin neden iyi kaynaklara işaret eden özelliklere odaklanma eğiliminde olduğunu açıklarken, erkekler doğurganlığın sinyallerine odaklanma eğilimindedir: dişiler eşlerini seçerler

Eş seçimi tercihlerindeki cinsiyet farklılıkları hakkındaki evrimsel hipotezler, Trivers' ın ebeveyn yatırım modelinden türetilmiştir. Bu model, kadınların, yavrularının hayatta kalma veya üreme olasılıklarını en üst düzeye çlkaran fiziksel olmayan özelliklere sahip bir eş aramaya erkeklerden daha olası olduğunu iddia ederek incelenmiştir ve eş seçimi araştırmasına dair bir meta-analizde araştırılmıştır. Tahmin edildiği gibi, kadınlar sosyoekonomik statü, hırslılık, karakter ve zekaya erkeklerden daha fazla ağırlık vermişlerdir ve en büyük cinsiyet farklılıkları kaynak edinme ipuçları (statü, hırslılık) için gözlemlenmiştir. (Feingold, 1992)

Diğer türlerde olduğu gibi insan erkeği de, doğan yavrunun kendisinin de yavrusu olup olmadığıyla fazlaca ilgilenmektedir. Dişilerin benzer biyolojik ilişkiye dair endişeleri bulunmamaktadır. Şüphesiz ki doğurduğu yavru kendisindendir ve istenmeyen gebelik durumları ve psikolojik bozulmalar hariç anne çoğunlukla yavrusunu kabullenmektedir. Bir dişi bir erkekten hamile kaldığında yaşadığı endişe genellikle kendisine ve yavrusuna sağlanacak kaynak üzerine yoğunlaşmaktadır. Erkeğin başka bir 
dişiden yavru meydana getirmesi, kaynakların bölünmesine ve yavrunun alabileceğinden daha az bakım almasına ve daha az gelişmesine sebebiyet verebilmektedir. Bunun sonucunda ise dişiler duygusal bağlllı̆a, erkekler ise cinsel bağlllı̆̆a önem vermektedir.

Bahsedilen cinsiyetler arasındaki farklılıklar sebebiyle dişi ve erkeklerin farklı çiftleşme endişeleri bulunmaktadır. Söz edildiği gibi, annelik kesindir ancak babalığın baba tarafından tayini mümkün olmayabilir. Bunun sonucunda ise bir erkek dişiye ve yavruya kaynaklarını aktarmaya karar verdiğinde, o yavrunun kendisine ait olduğuna emin olmak istemektedir. Bu tür üreme ile ilgili endişelerin sonucunda ise babalık güvencesi olarak adlandırılan ve türün erkeğinin genetik olarak kendisine ait olmayan herhangi bir yavru üzerine yatırım yapmak istememe durumu ile karşı karşıya kalınmaktadır. Neredeyse tüm türlerde erkekler, üreme başarısını, cinsel kıskançlık ve genetik olarak kendisine yakın olan yavruyu destekleyerek arttırmaya çalışmaktadır (Goetz, 2010). Böylece şiddet davranışı üreme başarısı ve kendini güvene alma mekanizması ile açıklanmaktadır. Eğer erkekler, kıskanç ama aynı zamanda risk almayan bir tutum sergileselerdi eşe karşı şiddet davranışı daha az görülebilirdi (Daly ve Wilson 1984). Bu durumla ilişkili olarak üvey ebeveyne sahip (özellikle baba) çocuklar göz önünde bulundurulduğunda, bu çocukların diğer çocuklardan 40 kat daha fazla istismar, suça itilme ve evden kaçma gibi istatistiklerde yer aldığı görülmektedir (Daly ve Wilson, 1984). Yapılan erkek ve kadın karşılaștırmasında, erkeklerin çocuklara karşı daha fazla orantısız şiddet uyguladığı, bunun sonucunda ise kadınlardan çok erkeklerin ölümcül çocuk istismarına sebebiyet verdiği bilinmektedir (Wilson, 2005).

İnsanlarda erkeklerin dişilere saldırması adaptif ise, benzer davranışların primatlarda da görülmesi gerekmektedir. Yapılan primat araştırmaları göstermektedir ki, erkek primatlar çiftleşme sırasında dişilerin direncini ortadan kaldırmak için saldırganlık ve şiddete başvurmaktadır (Goodall, 1986). Araştırmacılar, neredeyse orangutanlardaki çiftleşmelerin yarısının, dişilerin direnci erkek saldırganlığı ile kırıldıktan sonra gerçekleștiğini görmüşlerdir (Hanna, 1997).

Şiddet olgusu her ne kadar erkekler üzerinden açlklanmaya daha müsait olsa da kadınların da şiddet davranışı gösterdiği bilinen bir gerçektir. Kadınlardaki şiddet davranışını inceleyecek olursak, erkeklerde olduğu gibi bu davranışların da adaptif yönleri bulunduğunu görebilmekteyiz (Buss ve Duntley, 2011). Erkekler birbirlerine üstünlük kurma ve bunun getirdiği ödülleri elde etmek için şiddeti kullanırken, kadınların ise üreme başarısını arttırmasına yardımcı olan kaynaklar için şiddete başvurduğu görülmektedir (Campbell, 2001). Her iki cinsiyet için de üreme başarısı, olgunluğa ulaşan yavruların sayısı ile ölçülmektedir (Moreno, 2010). Kadınların şiddet davranışına başvurmadaki en önemli sebebi, üreme başarısını arttırmak ve bunun için de var olan yavrularını çevreden gelecek 
olan tehditlere karşı korumaktır. Hayatta kalmak için gerekli kaynakları ve korumayı sağlayabilmek için kadınların şiddete başvurması ve yavrularını korumasına yardımcı olacak eş seçimi için savaşması, gösterilen şiddet davranışının sebeplerindendir. Bu sebepten dolayı kaynaklara ulaşma gücü yüksek olan erkekleri eş olarak seçmiş dişilerin kaynaklara ulaşma şansı düşük olan erkeklerle eş olan dişilerden daha düşük şiddet davranışına başvurduğu söylenebilir (Campbell, 2001).

Evrimsel bakış açısıyla eșe karşı şiddet, cinsel sadakatsizlik, dişinin başka bir erkeğin yavrusunu taşıma şüphesi, kaynakların sınırlılığı, eşliğin sonlanması, eski eşin yeniden eş bulmasını engelleme (Buss ve Duntley, 2011) gibi adaptif problemler yoluyla açılamak hipotetik olarak mümkün olsa da, günümüzde kadına karşı şiddeti ve kadın cinayetlerini açıklama konusunda yetersiz kalmaktadır. İnsanlarda görülen şiddet davranışının evrimsel adaptasyonların ötesinde, toplumun ataerkil yapısından kaynaklanmakta olduğuna mutlaka dikkat çekmek gerekmektedir. Ataerkil düzenin sebebiyet verdiği kadına karşı üstün gelme çabası, kadının güç kazanmasını engelleme ve erkeğin gücünü sürdürmeye yönelik tutumu sonucunda kadına şiddet ve cinayet vakaları gün geçtikçe artmaktadır. Bununla birlikte verilen cezaların yetersizliği, temel eğitimin eksikliği ve medyanın kadına karşı şiddetle mücadelede etkin olmayan kullanımı, eşe karşı şiddet ve kadına yönelik şiddet olgusunu her geçen gün kadınların içinde bulunduğu durumu daha da vahim hale getirmektedir.

\section{Gruplar Arası Çatışma}

Modern tarihimiz boyunca insan grupları arasında çatışmalar meydana gelmiştir. Ülkeler arası savaşlar, terörizm, ırksal ve etnik ayrımcılık ve siyasi partiler arasındaki çatışmalar gibi büyük ölçekli çatışmalardan, rekabet, düşmanlık ve saldırganlık içeren nispeten küçük ölçekli çatışmalara kadar uzanmaktadır (Vught, 2009). Toplu şiddet, bir bireye karşı gerçekleştirilen şiddet davranışı değil, ekonomik veya sosyal hedeflere ulaşmak için kullanılan kolektif bir şiddet türüdür (Littman ve Paluck, 2015). Evrimsel açıdan bakıldığında toplu şiddet şiddet, evrimsel bir adaptasyon veya adaptasyonların bir yan ürünü olarak ele alınabilir (Durrant, 2011).

Grup dıșı sergilenen saldırganlığın açıklaması ise değerli olan kaynakların diğer gruplar tarafından erişiminin engellenmesi olarak açılanabilmektedir. Bireyin tek başına yüzleşemeyeceği durumlarda grup içinde var olması güç ve kaynak anlamında bireye yarar sağlamaktadır. Böylece hayatını devam ettirme ve genlerini bir sonraki kuşağa aktarma konusunda avantaj sağlamaktadır. Darwin'e göre $(1859$; 1871), ahlaki davranışlar doğal seçilim yoluyla evrimleşebilmektedir (Akt. Özgökman, 2015). Toplu şiddet, bu fikirden yola çıkarak, bireyin hayatta kalabilmesi için bir topluluk içinde var olması, tehlikelerle başa çımması ve hayatını sürdürmesine dair olanaklarının artması açısından fayda sağlamak olarak açlklanabilmektedir. Böylece ahlaki davranışların topluluklar içinde 
gelişmesi bireyler için avantajlı bir durum haline gelmektedir (Özgökman, 2015).

Zwi ve arkadaşları (2002) şiddetin araçsal kullanımını, belli bir grupta bulunan bireylerin karşı gruplara veya bireylere karşı şiddet uygulaması şeklinde tanımlanmıştır. Toplu şiddet belirli bir gruba ait olmayan bireylerin arasında gerçekleşen şiddet olgusundan daha farklı bir şekilde meydana gelmektedir. En önemlisi, toplu şiddet sosyal ikameyi (social substitutability) kapsamaktadır (Kelly, 2000). Sosyal ikame ise, bir kişinin belirli bir gruba karşı şiddet davranışının gerçekleştirilmesine karşın bireye yönelik olmaması olarak açıklanabilmektedir. Bazı nefret suçları, örneğin, bir cinsiyete, ırka veya cinsiyet yönelimine karşı, o grup herhangi kötü bir davranışta bulunmamış olsa bile, şiddet göstermek olarak tanımlanabilmektedir. Bazı terörizm biçimleri de bu kapsam içinde sayılmaktadır.

Gruplar arası çatışma, kaynak kıtllğı sebebiyle gerçekleşmektedir ( Sidanus ve Pratto, 1999). Toplu şiddet olgusuna dair ortaya atılmış dört adet hipotez bulunmaktadır. Bunlar; denge eşitsizliği hipotezi, bilinçli erkek koalisyonel üreme stratejisi olarak savaş, erkek savaşçı hipotezi ve gruba has özgecilik hipotezi olarak bilinmektedir (Gat, 2006; Smith, 2007). Denge eşitsizliği hipotezi şempanzelerdeki gruplar arası şiddet incelemeleri sonucu elde edilmiş ve insanlar arasındaki toplu şiddeti açılamak için uyarlanmıştır. Bu hipoteze göre, toplu şiddet iki faktör sebebiyle meydana gelmektedir. Bunlar; gruplar arası saldırganlık ve gruplardaki güç eşitsizlikleridir (Wrangham, 1999). Toplu saldırganlık, endemik ve sürekli gruplar arası bir özellik değildir ancak güç dengesizlikleri ile meydana gelmektedir. Toplu saldırganlığın evrimsel fonksiyonu ise diğer gruplara karşı üstünlügü göstermek, kaynaklara yani yiyecek, eş ve barınmaya ulaşım olarak ifade edilebilir. Van der Dennen (2002) ise toplu şiddeti bilinçli erkek koalisyonel üreme stratejisi ile açıklamaktadır. Savaş gruplar için daha iyi bölgelere/kaynaklara ulaşımı ve üreme şansını arttırma açısından fayda sağlamaktadır. Koalisyon oluşturma ve grup bölgesinin belirlenmesinin de savaşı için ön koşullar olarak düşünülmektedir. Erkek savaşı hipotezinde (Van Vught, 2009), toplu şiddetin evrimsel hipotez ile iki noktada birleştiğinden bahsedilmektedir. Van Vught (2009) gruplar arası çatışmanın insan evriminde erkek koalisyonel psikolojisini yansıttığını, çünkü erkeklerin toplu şiddet aracılığıyla yiyecek ve eşleşme imkânına ulaşabildiklerini savunmuştur. Bu sebepten dolayı dişi ve erkeklerin gruplar arasında psikolojik açıdan ayrıştığını savunmaktadır. Örneğin; erkeklerin gruplar arası deneyimlerde daha yarışçı olması, kendi grubuna bağlığının yüksek olması ve savaş için daha fazla politik destek aramalarının sebebinin bu olabileceği düşünülmektedir. Choi ve Bowles (2007)' a göre ise savaş ve gruba has özgecilik, gruplar arası çatışma sonucu evrilmiştir. Bowles (2008) bunun evrimsel bakış açısından bakıldığında özgeciliğin ve gruba aidiyetin birey için aslında masraflı bir davranış olmasına rağmen elde edilen kaynaklar sayesinde bu durum dengelendiğini ifade etmektedir. Grup 
üyeleri ile iş birliği kuran ve karşı gruba saldırgan davranışlar sergileyen grup bireyleri, kendi açısından kaynaklara ulaşmada öncelik kazanmakta ve bu tür bireylere sahip olmayan gruplara karşı kendi grubu ile birlikte üstünlük sağlamaktadır. Böylece toplu olarak gösterilen şiddet davranışlarının, grubun sahip olduğu çıkarları koruma açısından ve daha fazla kaynak edinme açısından elverişli olduğu düşünülebilir (Sidanus ve Pratto, 1999). Her ne kadar grupta bulunan bireylerin akrabalık ilişkileri olmasa veya zayıf olsa da, gösterilen şiddet davranışı sonucunda elde edilecek ve/veya korunacak olan kaynakların bireysel çabalarla elde edilemeyecek olması toplu şiddeti avantajlı kılmaktadır. $\mathrm{Bu}$ evrimsel hipotezlerin ortak ve farklı noktaları olmasına karşın çoğunlukla benzerlik gösterdiği görülmektedir. Üreme bașarısının artması, diğer grupları ortadan kaldırarak güvenliğin artması, toplu şiddetin evrimsel yararları arasında sayılabilir.

\section{Öz Kıyım}

Öz kıyım davranıșını, evrimin ilk kuralı olan hayatta kalma ve üreme başarısıyla bağdaştırmak oldukça zordur. Evrimsel bakış açısına göre bir kişinin kendi canını alması pek de doğal olan bir süreç olarak kabul edilmemektedir. Evrimsel psikoloji, bireylerin hayatta kalma şansını arttırmaya yönelik olan mekanizmaların zaman içinde geliştirmesi üzerine kuruludur. Öz kıyım ise üreme başarısı şansı açısından ele alındığında, ölen birey genlerini bir sonraki kuşağa aktaramayacağı, en azından sağlıklı bir şekilde aktardığından emin olamayacağı bir gerçektir. Catanzaro (1991,1995) öz kıyımın evrimsel hipotezini test etmek için genel örneklemden ve yüksek riskli örneklemden (yaşlı ve psikiyatrik bozukluğu olan kişilerden) veriler toplamıştır. Catanzaro (1995), öz kıyımın, bireyin kendi toplam seçilim değerini (bir bireyin hayatta kalma ve yavru üretme imkanı) sağlayamadığında ortaya çıktığı yönünde bir sonuç öne sürmüştür. Bu evrimsel öz kıyım hipotezini açıklamak için Catanzaro (1995), kişilerde intihara eğilimli düşünceleri ölçtüğünde; aile, toplum, cinsel aktivite sıklığı, arkadaş sayısı, karşı cins ile olan arkadaşlık, eșcinsellik, diğer insanların kendisine karşı davranışları, finansal rahatlık ve fiziksel sağlığın öz kıyım ile ilişkili değişkenler olduğu gösterilmiştir.

Evrimsel başarı, kapsayıcı uyum başarısı (inclusive fitness) 'na bağlıdır (Aubin, Berlin ve Kornreich, 2013). Kapsayıcı uyum başarısı; doğrudan uyum başarısı (bireyin üreme ve hayatta kalma başarısı) ile dolaylı uyum başarısının (bireyin akrabalarının üreme başarısından kaynaklı evrimsel başarısıdır) toplamı olarak ifade edilebilmektedir (Freeman ve Herron, 2001). Fedakar/özgeci intihar hipotezi, düşük üreme potansiyeli ve akrabalara karşı yükün varlığıyla canlının kendi kendini uzaklaştırmakla kapsayıcı uyum başarısının (inclusive fitness) getirisini arttırabileceğini öne sürmektedir (de Catanzaro, 1991). Öte yandan öz kıyıma farklı bir bakış açısından bakan pazarlık hipotezine göre, öz kıyım girişimlerinin bir ihtiyaç sinyali olarak görülmesi gerekmektedir (Watson ve 
Andrews, 2002). Bu bireyler grup içinde yeterince yarar sağlayamadığında, üreme başarısı düşük olduğunda hatta gruba zarar verdiğini düşündüğünde öz kıyım girişiminde bulunabilmektedir. Sonuç olarak öz kıyım evrimsel psikoloji bakış açısıyla ele alındığında, seçilim değeri düşük olan kişilerin hayatta kalma isteklerinin de düşük olması şeklinde açılanabilmektedir.

\section{Cinayet}

Buss ve Duntley (2005) insanların türdeşlerini öldürmek üzere adaptasyonlar edindikleri hipotezini öne sürmüştür. Cinayet için psikolojik adaptasyonları, doğal seçilim sürecinin bir sonucu olarak görülmektedir. Tüm adaptasyonlar gibi atalarımızın yaşadığı problemlere daha iyi çözümler bulmaya katkı sağladığı düşünülmektedir (Buss ve Duntley, 2005). Eski çağlarda bazı problemli durumların cinayet davranışı ile çözüme kavuşturulabildiği savunulmuştur. Bu durumların ise yaralanma, tecavüz, kendini ve yakınını ölümden koruma, saygınlığı elde tutma, kaynakları koruma ve genetik olarak daha iyi durumda olan kişilere daha iyi kaynaklar sağlayabilmek için genetik durumu kötü olanı ortadan kaldırma olduğu söylenmektedir. Cinayet, kendine has ve potansiyel olarak yapan kişiye ve yapılana karşı büyük sonuçlar doğurabilecek güçlü bir stratejidir. Öldürülen kişiler doğal olarak kendi ölümlerine sebebiyet veren kişi ile savaşamaz ve o kişinin çevresini etkileyemez. Bu elde edilen sonuca göre psikolojik mekanizmaları şekillendirmiş ve bazı durumlarda diğer stratejileri kullanmaktansa, cinayet işleme davranışını gösterme, kişiye daha fazla kar sağlayabilmektedir (Buss ve Duntley, 2005).

İnsanlık tarihi boyunca, saygınlık kazanma ve sosyal statü açısından sürekli çatışma hali yaşanmıştır. Bir başkasını öldürme, evrimsel bakış açısıyla, doğal seçilim ile şekillenen ve çatışmanın sonucu olan duruma bağlı bir strateji olarak değerlendirilebilir. Cinayet ile ilgili adaptasyonların, adaptif problemle ilgili bir sorunu çözdüğü durumlara karşı evrilmiş olması her zaman daha olasıdır. Örneğin, bir erkeğin aynı cinsten olan rakibinin, onun hiyerarşik statüsünün yükselmesine engel olan, potansiyel eşleri uzaklaştırdığı ve her firsatta onu güçsüzleştiren bir durumda kaldığında, o kişinin ortadan kaldırılması daha yararlı olmaktadır. Kısacası, cinayet adaptasyonu hipotezi, birkaç psikolojik adaptasyon ile şekillenmiş, aşikâr ve geçmişe ait problemleri çözmeye odaklanmış olduğu şeklinde açıklanmaktadır (Buss ve Duntley, 2005, 2011).

\section{Tecavüz}

Cinsel baskı ve tecavüz pek çok canlı türünde görülen bir cinsel şiddet türüdür. Tecavüzün evrimsel teorisi, cinsel baskı ve tecavüzün, erkeklerin daha saldırgan, çiftleşmeye daha hevesli, cinsel olarak iddialı ve eş seçiminde fazla ayrım yapmayan türlerde daha fazla meydana geldiğini ortaya koymaktadır (Thornhill ve Palmer, 2000). Bu hipotez, tecavüzü evrim teorisi ile açılamaya çalışmakta ve tecavüzün atalarımızın üreme başarısını artıran kalıtsal mekanizmalarla doğrudan veya dolaylı olarak ilişkili 
olduğunu ileri sürmektedir Thornhil ve Palmer, hipotezlerini desteklemek amacıyla bir olumlu ve bir olumsuz olmak üzere iki ana argüman sunmaktadır. Olumlu argüman; tecavüz hakkındaki evrimsel açıklamaları, deneysel yeterliliği ve açıklayıcı derinliği kapsamaktadır.

Tecavüzün psikolojik mekanizmalarda evrimleşmiş olması için, geçmişteki tecavüzcülere üreme açısından fayda sağlamış olması gerekmektedir. Bu faydaların meydana gelebilecek zararlardan daha fazla olması davranışın devamlılığı için şarttır. Zararların yanı sıra, tecavüz edilen kadınlar ve tecavüz eden erkeklerin üremesi açısından artış olduğu görülmektedir (Gottschall ve Gottschall, 2003; Thornhill ve Palmer, 2000). Thornhill ve Palmer tecavüzün erkekler için üreme avantajı ile sonuçlanması sebebiyle ya doğrudan seçilmiş bir adaptasyon olduğunu veya diğer sorunları çözebilme sebebiyle adaptasyonun yan ürünü olduğunu söylemektedir (Ward ve Siegert, 2002). Araștırmacılar özellikle (Thornhill ve Thornhill, 1992; Thornhill ve Palmer, 2000), birkaç olası tecavüz adaptasyonunun olduğundan bahsetmiştir. Bu adaptasyonların evrensel erkek psikolojisi özelliklerine sahip olduğu ve bazı durumlarda harekete geçtiği ifade edilmiştir. Tecavüz için evrimsel psikolojik teorilerin bilimsel desteği çeşitlilik göstermektedir. Örneğin; erkeklerin cinsel birleşmeye limitli veya ulaşımı olmadığı durumlarda bu tür davranışlara başvurduğu gözlemlenmektedir. Ortaya atılan tecavüz adaptasyonlarına ait hipotezlerde erkeklerin standart bir eş seçiminden farklı olarak tecavüz edeceği kişinin cinsel olarak çekiciliğini değerlendirdiği ifade edilmektedir. Böylece, tecavüzcünün üreme açısından, bir seferlik de olsa zorla ilişkiye girmenin, ilişkinin hamilelik ile sonuçlanmasını arttırdığı düşünülmektedir. Bu hipoteze göre, tecavüzcülerin hamile kalma olasılıkları yüksek olan dişileri hedef aldığı belirtilmektedir (Thornhill ve Palmer, 2000). Pek çok araştırmada, genç kadınların doğurganlıklarının tepe noktası olduğu zamanlarda tecavüzcüler tarafından hedef alındığı görülmüştür (Ghiglieri, 2000; Thornhill ve Thornhill, 1992)

Araştırmacılar bazı kadın özelliklerinin tecavüz ile karşılaşma riskini azalttığından bahsetmişlerdir. Smuts (1992) kadın ve erkeklerden oluşan grupların tecavüz riskini azalttığını öne sürmüștür. Wilson ve Mesnick (1997), kadınların eş seçimlerinin fiziksel ve sosyal olarak baskın erkeklerden yana olmasının tecavüze karşı bir adaptasyon olduğunu belirtmektedir. Son olarak ise, Davis ve Gallup (2006) kendiliğinden gelişen düşüklerin ve gebelik zehirlenmelerinin kadınların tecavüze karşı bir adaptasyonu olabileceğinden bahsetmişlerdir. Ancak bu konuyla ilgili araştırmaların yetersiz kaldığı ve daha çok bilgi elde edilmesi gerektiği düşünülmektedir.

\section{Sonuç ve Tartışma}

Şiddeti, evrimsel psikolojik bakış açısıyla açıklamak bazı noktalarda mümkün olsa da şiddet olgusunu tek bir bakış açısıyla açıklamak oldukça güçtür. Toplumun kültürel ve ahlaki yapısı, bireysel ve çevresel faktörler 
şiddeti açıklamada yardımcı olabilecek diğer faktörler arasında sayılabilmektedir. Şiddet davranışının ahlaki kurallara ters düşmesinden dolayı bu davranışlar ahlaki açıdan ele alındığında açıklanması zor ve toplumun normlarına aykırı davranış biçimi olarak düşünülebilir. $\mathrm{Bu}$ nedenle evrimsel açıdan bakıldığında şiddet davranışına sebebiyet veren adaptasyonların ve mekanizmaların hayatta kalabilme adına zaman içerisinde kalıcı hale geldiğini söylenebilir.

Önceden de sözü edildiği üzere, evrimsel psikoloji, şiddet davranışını bireylerin adaptasyon ve hayatta kalma içgüdülerinin bir yan ürünü olarak ortaya çıkan davranışlar olarak açıklamaktadır. Bu, bireyin yaşama şansını arttırmaktaki rolünün yanı sıra diğer bireylere zarar verme olasılığının oldukça yüksek olduğu bir davranış olarak açıklanabilir. Her ne kadar şiddet davranışı bireyin kaynaklarını koruma, yaşam kalitesini arttırma, genlerini bir sonraki kuşağa aktarma şansını arttırsa da zaman içinde bu davranış kültürün de etkisiyle farklılaşarak istenmeyen sonuçlara neden olmuştur. Bu sebepten dolayı gerek eșe karşı şiddet olgularını gerekse başka bireylere karşı gösterilen şiddet davranışını sadece evrimsel psikolojik bakış açısıyla açıklamak mümkün olmamaktadır. Bu bakış açısı insan yaşamının temelinde var olan bazı mekanizmalardan ileri gelse de insanların sosyal birer varlık olmaları sonucunda ahlaki değerler taşıma zorunlulukları toplum içinde var olma şanslarını arttıran bir diğer faktördür. Bu ahlaki değerler ile şiddet davranışının çatıştığı durumlarda ise toplum dışına itilmesi olası bir durum olarak karşımıza çıkar. Her ne kadar şiddet davranışı hayatta kalma içgüdüsünün bir ürünü olsa da bu davranışın ahlaki değerler çerçevesinde yerine getirilmesi pek mümkün olmamaktadır.

\section{KAYNAKÇA}

Aubin, H. J. - Berlin, I. - Kornreich, C. (2013). The evolutionary puzzle of suicide. International Journal of Environmental Research and Public Health, 10(12), 6873-6886.

Bowles, S. (2008). Conflict: Altruism's Midwife. Nature, 456, 326-327.

Buss, D. M. - Gomes, M. - Higgins, D. S. - Lauterbach, K. (1987). Tactics of manipulation. Journal of Personality and Social Psychology, 52(6), 1219-1229.

Buss, D. M. - Duntley, J. D. (2005). The plausibility of adaptations for homicide. The Innate Mind: Structure And Contents, ABD: Oxford University Press.

Buss, D. M. - Duntley, J. D. (2011). The evolution of intimate partner violence. Aggression and Violent Behavior, 16(5), 411-419.

Buss, D. (2018). The evolution of love in humans. The New Psychology of Love, (Eds.: R. Sternberg ve K. Sternberg), 42-63, Cambridge: Cambridge University Press.

Bufill E. - Blesa R. - Augustí, J. (2013). Alzheimer's disease: an evolutionary approach. Journal of Anthropolgy Sciences, 91, 135-157.

Bouchard Jr, T. (2014). Genes, evolution and intelligence. Behavior Genetics, 44, 6.

Choi, J. K. - Bowles, S. (2007). The coevolution of parochial altruism and war. Science, $318,636-640$. 
Cosmides, L. - Tooby, J. (2000). Evolutionary psychology and the emotions. Handbook Of Emotions, (Eds.: M. Lewis - J. M. Haviland-Jones), 2nd ed., 91115, New York: Guilford Press.

Crawford, C. B. - Anderson, J. (1989). Sociobiology: An environmentalist discipline?. American Psychologist, 44, 1449-1459.

Davis, J. A. - Gallup, G. G. Jr. (2006). Preeclampsia and other pregnancy complications as an adaptive response to unfamiliar semen. Female Infidelity And Paternal Uncertainty, New York: Cambridge University Press.

De Catanzaro, D. (1991). Evolutionary limits to selfpreservation. Ethology And Sociobiology, 12, 13-28.

De Catanzaro, D. (1995). Reproductive status, family interactions, and suicidal ideation: Surveys of the general public and high-risk group. Ethology And Sociobiology, 16, 385-394.

Diamond, J. (1997) Why sex is fun: The evolution of human sexuality. ABD: W\&N.

Duntley, J. D. (2005). Adaptations to dangers from other humans. The Handbook of Evolutionary Psychology, New York: Wiley.

Durrant, R. (2011). Collective violence: An evolutionary perspective. Aggression and Violent Behavior, 16, 428- 436.

Feingold, A. (1992). Gender differences in mate selection preferences: a test of the parental investment model. Psychological Bulletin, 112(1), 125-39.

Gat, A. (2006). War in human civilization. Oxford: Oxford University Press.

Ghiglieri, M. P. (2000). The dark Sside of man. New York: Perseus Books.

Goetz, A.T. (2010). The evolutionary psychology of violence. Psicothema, 22 (1), 1521.

Goodall, J. (1986). The chimpanzees of Gombe: Patterns of behavior. The Belknap Press of Harvard University Press: Cambridge, Massachusetts.

Gottschall, J. A. - Gottschall, T. A. (2003). Are per-incident rape-pregnancy rates higher than per-incident consensual pregnancy rates?. Human Nature, 14, 120.

Hanna, C. (1997). Can a biological inquiry help reduce male violence against females? Or what's a nice "Gal" like me doing at a conference like this. Vermont Law Review, 333, 340-341.

Kadının Statüsü Genel Müdürlüğü (2019). Türkiye'de kadın, 1-78, Ankara: Aile, Çalışma ve Sosyal Hizmetler Bakanlığı.

Kelly, R. C. (2000). Warless societies and the origin of war. Ann Arbor, MI: The University of Michigan, Michigan Press.

Littman, R. - Paluck, E. L. (2015). The cycle of violence: Understanding individual participation in collective violence. Advances in Political Psychology, Vol. 36, Suppl. 1.

Marlborough, C. (2003). Evolution, child abuse, and the constitution. Journal of Law and Policy, 687.

Moreno, J. (2010). Reproductive success. Encyclopedia of Animal Behavior, 64-69.

Polat, O. (2017). Şiddet. Marmara Üniversitesi Hukuk Fakültesi Hukuk Araştırmaları Dergisi, 22 (1),15-34. 
Sidanius, J. - Pratto, F. (1999). Social dominance: An intergroup theory of social hierarchy and oppression. New York, NY: Cambridge University Press.

Smith, D. L. (2007). The most dangerous animal: Human nature and the origins of war. New York, Ny: St. Martin's Press.

Smuts, B. B. (1992). Male aggression against women. Human Nature, 6, 1-32.

Thornhill, R. - Palmer, C. P. (2000). A natural history of rape. Cambridge, MA: MIT Press.

Thornhill, R. - Thornhill, N. (1992). The evolutionary psychology of men's coercive sexuality. Behavioral And Brain Sciences, 15, 363-375.

Tooby, J. - Cosmides, L. (1992). The psychological foundations of culture. The Adapted Mind: Evolutionary Psychology And The Generation Of Culture, (Eds.: J. H. Barkow, L. Cosmides, J. Tooby),19-136, New York: Oxford Univ. Press.

Trivers, R. L. (1972). Parental investment and sexual selection. Sexual Selection And The Descent Of Man, (Ed.: B. Campbell), 136-179, Chicago, IL: Aldine

Van Der Dennen, J. M. G. (2002). (Evolutionary) Theories of warfare in preindustrial (foraging) societies. Neuroendocrinology Letters, 55-65.

Van Vught, M. (2009). Sex differences in intergroup competition, aggression, and warfare: The male warrior hypothesis. Annals of The New York Academy of Science, 1167, 124-134.

Ward, T. - Siegert, R. (2002). Rape and evolutionary psychology: A critique of Thornhill and Palmer's theory. Aggression and Violent Behavior, 7(2), 145 168.

Watson, P. J. - Andrews, P. W. (2002) Toward a revised evolutionary adaptationist analysis of depression: The social navigation hypothesis. The Journal of Affect. Disorders, 72, 1-14.

Wilson, M. - Daly, M. (1984). Competitiveness, risk-taking, and violence: The young male syndrome. Ethology And Sociobiology, 61.

Wilson, M. J. W. (2005). Evolutionary perspective on male violance: Practical and policy implications. American Journal of Criminal Law, 291-323.

Wilson, M. - Daly, M. (1999). The Truth About Cinderella.

Wilson, M. - Mesnick, S. L. (1997). An empirical test of the bodyguard hypothesis, feminism and evolutionary biology. New York: Chapman ve Hall.

Wrangham, R. (1999). Evolution of coalitionary killing. Yearbook of Physical Anthropology.

Zwi, A. B. - Garfield, R. - Loretti, A. (2002). Collective violence. Geneva: World Health Organization.

\footnotetext{
“İyi Yayın Üzerine Kılavuzlar ve Yayın Etiği Komitesi’nin (COPE) Davranış Kuralları" çerçevesinde aşağıdaki beyanlara yer verilmisstir. / The following statements are included within the framework of "Guidelines on Good Publication and the Code of Conduct of the Publication Ethics Committee (COPE)":

İzinler ve Etik Kurul Belgesi/Permissions and Ethics Committee Certificate: Makale konusu ve kapsamı etik kurul onay belgesi gerektirmemektedir. / The subject and scope of the article do not require an ethics committee approval.

Çıkar Çatışması Beyanı/ Declaration of Conflicting Interests: Bu makalenin araştırması, yazarlığı veya yayınlanmasıyla ilgili olarak yazarın potansiyel bir çıkar çatışması yoktur. / There is no potential conflict of interest for the author regarding the research, authorship or publication of this article.
} 